\title{
Caso radiológico para diagnóstico
}

Drs. Patricio Latorre $B^{(1)}$, Holvis Dellien $Z^{(2)}$, Ricardo Wenger $C^{(3)}$, Fernando Carreño $A^{(3)}$.

1. Residente de Radiología. Facultad de Medicina Clínica Alemana - Universidad del Desarrollo. Chile.

2. Servicio de Diagnóstico por Imágenes. Facultad de Medicina Clínica Alemana - Universidad del Desarrollo. Chile.

3. Fellow Servicio de Neuroimágenes. Facultad de Medicina Clínica Alemana - Universidad del Desarrollo. Chile.

\section{Caso clínico}

Mujer de 34 años. Se le solicita una resonancia magnética de cerebro por control de meningiomas.

\section{¿Cuál es su diagnóstico?}

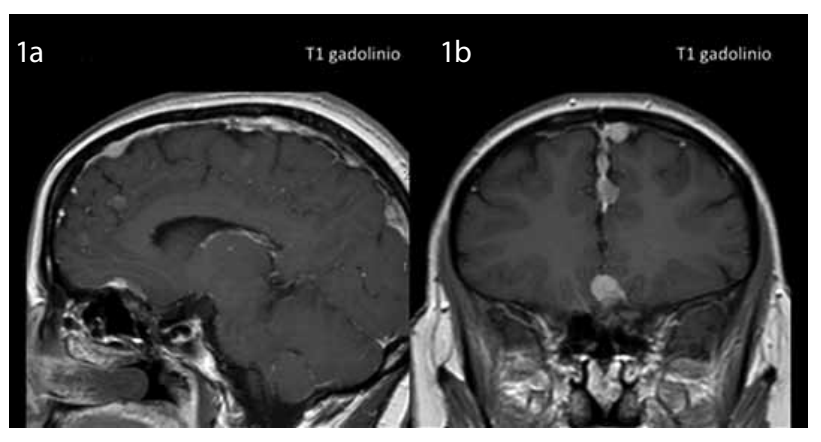

Figura 1a,b.

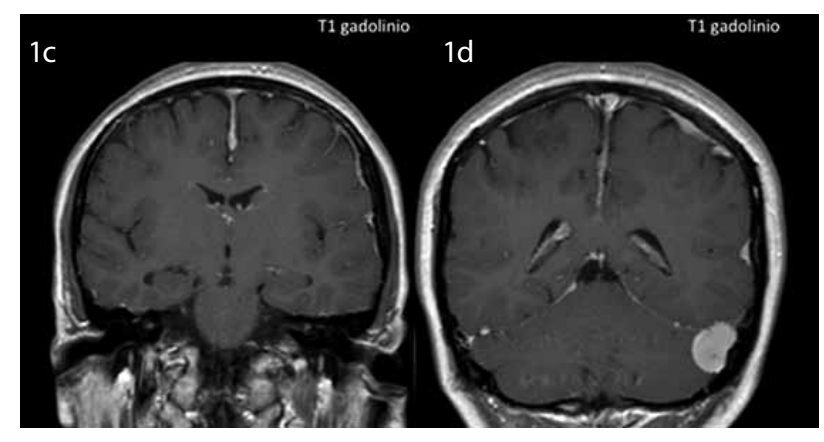

Figura 1c,d. 